The tubercles are small and scarcely discernible except on anal segments, where they are outlined with black. There is a dark stripe along the spiracles, which are black. No filaments. Ventral surface pink, with all the spots black and conspicuous.

May 2 oth, spun up. Pupa: length, one and one-tenth inches; width, three-tenths inch. Gave imago June r $9^{\text {th. }}$

Catocala habilis, Grt.

Larva taken early in June, under loose bark on hickory. Food-plant, hickory.

June I6th. Length, two and two-tenths inches. Colour, greenish black; very smooth and glossy. Head wider than first segment, pale, with slight brown markings, and with a broad, irregular, black stripe from mouth to top of lobes. The dorsal stripe scarcely paler than the general colour. 'Tubercies whitish, minute. No ridge or prominence and no transverse band. No filaments.

A very black stigmatal stripe, distinct to the extremities, forms a sharp line of demarcation between the blackish colour above and the greenish gray of the sub-stigmatal region. Ventral surface greenish white, with dusky spots on the central segments only. Spun up June 2znd. Gave imago July $\mathrm{I} z$ th, I $90 \mathrm{I}$. The larva of habilis and Judith are very similar in appearance and habits, but may be readily distinguished from each other by the black stigmatal stripe and black marks on the head of the former. Occasional larvæ are much paler in general colour, but retain these distinctive markings.

\title{
A NEW VARIETY OF CICINDELA VULGARIS.
} BY EDWARD DOUBLEDAY HARRIS, NEW YORK.

A undescribed variety of Cicindela valgaris, Say, is reported from the basin of the Rogue River, in S. W. Oregon. Twenty specimens taken during the month of April of this year, and closely representative of the local tribe, present no differences except a slight one in shade of colour, indicating, apparently, that the variety is well established and worthy of a descriptive name. The elytra markings are identical with those generally recognized as possessed by vulgaris proper. It is slightly narrower and the upper surface more convex than the type. The colour is a dull coppery green, the metallic hue being more apparent, as is usual in other species, at the edges of the elytra. It seems to be a connecting link between the type and variety vibex, Horn. Its habitat suggests the name C. roguensis. 